\title{
Spatial variability in the icthyoplankton structure of a subtropical hypersaline lagoon
}

\author{
Judson da Cruz Lopes da Rosa ${ }^{1}$, Mariana Dantas Alberto ${ }^{1}$, Wanda Maria Monteiro Ribas ${ }^{2}$, Maria \\ Helena Campos Baeta Neves ${ }^{2}$, Lohengrin Dias de A. Fernandes ${ }^{2}$
}

\footnotetext{
${ }^{1}$ Universidade Federal Fluminense.

${ }^{2}$ Instituto de Estudos do Mar Almirante Paulo Moreira.

*Corresponding author: judsoncruz@yahoo.com.br
}

\begin{abstract}
The Lagoa de Araruama is a hypersaline ecosystem inhabited by distinct fish species, either permanently or during their reproductive season. Over recent years, some significant environmental changes have been observed in this ecosystem related to the sewage runoff, as salinity decrease (from 64 to 41 psu during the last 40 years) and nutrients increase. As both changes are thought to affect the ichthyoplankton assemblage, the present study aimed to evaluate all the potential relationships between salinity disruption and fish larvae distribution. Ichtyoplankton samples were collected monthly from January 2010 to March 2011 at eight sites in Araruama Lagoon by means of a WP2 plankton net equipped with a flowmeter. During this period, low egg densities were coincident with high salinity regions, suggesting that adults are avoiding to release their eggs under less favorable environmental conditions to the larvae. The uneven distribution of eggs and larvae inside the lagoon, as revealed by both spatial and temporal analyses lead us to suggest that changes in salinity have influenced the reproductive rhythms of those fish species that depend upon the Lagoa de Araruama.
\end{abstract}

Descriptors: Icthyoplankton, Hypersaline lagoon, Lagoa de Araruama, salinity.

\section{RESUMo}

A Lagoa de Araruama é uma laguna hipersalina habitada por diferentes espécies de peixes, permanentemente ou durante a estação reprodutiva. Nos últimos anos, algumas alterações ambientais têm sido observadas nesse ecossistema, relacionadas ao lançamento de esgoto in natura, como por exemplo decréscimo de salinidade (de 64 para 41 durante os últimos 40 anos) e aumento da disponibilidade de nutrientes. Considerando que ambas as mudanças podem afetar a assembléia do ictioplâncton, o presente estudo teve como objetivo avaliar todas as relações potenciais entre alterações na salinidade e distribuição de larvas de peixes. As amostras de ictioplâncton foram coletadas mensalmente a partir de janeiro de 2010 a março de 2011, em oito estações fixa na Lagoa de Araruama por meio de uma rede WP2 equipada com fluxômetro. Durante este período, baixas densidades de ovos coincidiram com áreas de alta salinidade, sugerindo que os adultos parecem estar evitando liberar os seus ovos em condições ambientais desfavoráveis às larvas. A distribuição desigual de ovos e larvas dentro da lagoa, como revelado pela correlação linear na variação espacial e temporal, sugere que as mudanças na salinidade influenciaram o ritmo reprodutivo das espécies de peixes que dependem da Lagoa de Araruama.

Descritores: Ictioplâncton, Laguna hipersalina, Lagoa de Araruama, Salinidade. 


\section{INTRODUCTION}

Coastal lagoon environments, ranging from continental waters to hypersaline waters, constitute significant sources for fisheries in different countries worldwide (DAY et al., 1989). Any lagoons that exhibit a mixture of fresh and marine waters, but also high evaporation rates are usually considered hypersaline coastal lagoons (SILVA et al., 2005). Most fish species that inhabit coastal lagoons are transitional, growing in the sea and returning later to the coast in the breeding season to release their offspring. By hatching in more protected areas, these species can increase the chances of their larvae meeting their nutritional requirements. Despite the high predation rate at the coast, some fish species are permanent and complete their full life cycle within a coastal lagoon (REYIER; SHENKER, 2007).

There is no consensus about how many fish species develop in estuaries and some studies have indicated variations between estuaries (CASTRO; BONECKER, 1996; BARTELLA-BERGAN et al., 2002) and between years (CASTRO; BONECKER, 1996; CASTRO et al., 2005; BONECKER et al., 2009). Gobiidae, Sciaenidae, Engraulidae, and Clupeidae are usually the most abundant families found in Brazilian estuaries and coastal lagoons (JOYEUX et al., 2004) but mainly so during the austral spring and summer (CASTRO et al., 2005; FRANCO; MUELBERT, 2003; AROCKIAMARY et al., 2011; KATSURAGAWA et al., 2011).

Distinct factors, such as food availability and larval skill in avoiding predation (PEPIN et al., 2003) and also physiological tolerance to temperature and salinity oscillations during tidal cycles, are known to affect larval survival in estuaries and coastal lagoons (REYIER; SHENKER, 2007). Salinity is a particularly important factor for the metabolic survival of eggs and fish larvae distribution because it can affect the osmotic balance by decreasing ion concentrations (OPSTAD, 2003).

Hypersaline marine ecosystems occur in a very few limited spatial extensions in the oceans and despite their importance for traditional fisheries in small cities, such areas have received little attention from scientists (COTNER, 2004). The "Lagoa de Araruama" is a locally important hypersaline lagoon (COUTINHO et al., 1999) that can help us to better understand the salinity effects upon the ichthyoplankton assemblage. The present study aimed to evaluate the influence of a salinity gradient upon the spatial variability of fish eggs and larvae in a subtropical hypersaline lagoon (Lagoa de Araruama).

\section{MATERIAL AND METHODS}

Data on salinity, temperature, dissolved oxygen, and larval abundance and composition were obtained at 8 strategic sites, defined a priori according to their proximity to sewage discharges as follow: Boqueirão (station 1), Monte Alto (station 2), Centro de São Pedro da Aldeia (station 3), Enseada de Iguaba (station 4), Ponta do Acaíra (station 5), Barbudo (station 6), Centro de Araruama (station 7), and Ponta dos Excursionistas (station 8) (Figure 1). Stations 2, 3 and 7 are those with the highest untreated sewage discharges. Ten collections were conducted, obtaining a total of 80 samples by means of horizontal surface hauls with $200 \mu \mathrm{m}$ mesh nets each with a $60 \mathrm{~cm}$ diameter opening and a coupled flowmeter.

In 2010, collections were conducted from January to June and from October to December; in 2011, they took place from January to March. It was not possible to standardize the tide at the collection time, which ranged between ebb and flood (Jan.10, ebb; Feb.10, ebb; Mar.10, ebb; May.10, flood; Oct.10, ebb; Nov.10, ebb; Dec.10, flood; Jan.11, ebb; Feb.11, ebb; Mar.11, flood). To evaluate the potential effect of continental runoff upon ichthyoplankton abundance, major environmental parameters, namely salinity, temperature, dissolved oxygen $\left(\mathrm{m} . \mathrm{L}^{-1}\right)$, and $\mathrm{pH}$ were measured during the survey. These parameters have been considered related to continental runoff, mainly sewage discharge in bays and estuaries (PEREIRA, 2007). All data were standardized and contrasted with previous data provided by MUREB (1982) and CASTRO et al. (1999) for the same region in order to check for long term change (Table 1).

Immediately after their collection, samples were fixed in a $4 \%$ formalin solution diluted in water from the lagoon and previously neutralized with sodium tetraborate. All eggs and larvae in collected samples were counted and

Table 1. Latitude, longitude, and station depth over the data collection period.

\begin{tabular}{lcccccccc}
\hline Stations & 1 & 2 & 3 & 4 & 5 & 6 & 7 & 8 \\
\hline Latitude & $22^{\circ} 53^{\prime} 10$ & $22^{\circ} 54^{\prime} 56$ & $22^{\circ} 50^{\prime} 47$ & $22^{\circ} 51^{\prime} 10$ & $22^{\circ} 53^{\prime} 42$ & $22^{\circ} 52^{\prime} 42$ & $22^{\circ} 53^{\prime} 19$ & $22^{\circ} 54^{\prime} 19$ \\
Longitude & $42^{\circ} 06^{\prime} 08$ & $42^{\circ} 05^{\prime} 38$ & $42^{\circ} 06^{\prime} 44$ & $42^{\circ} 12^{\prime} 15$ & $42^{\circ} 14^{\prime} 17$ & $42^{\circ} 17^{\prime} 15$ & $42^{\circ} 19^{\prime} 27$ & $42^{\circ} 21^{\prime} 34$ \\
Depth/meters & 2.3 & 1.4 & 2.2 & 3.7 & 5.9 & 3.4 & 2.1 & 1.2 \\
\hline
\end{tabular}




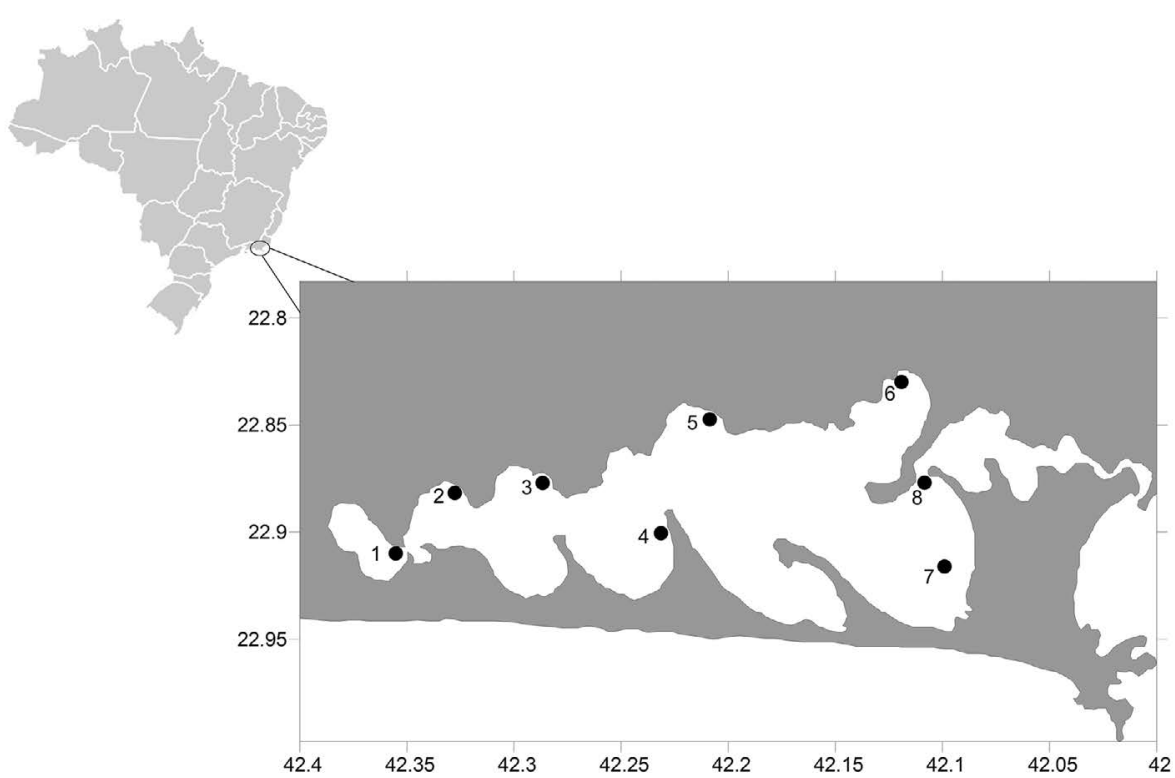

Figure 1. Map of the Rio de Janeiro state coast highlighting the 8 sampling stations in Lagoa de Araruama.

identified to the best taxonomical status under a Zeiss Discovery stereomicroscope. The values were extrapolated to eggs. $100 \mathrm{~m}^{-3}$ and larvae. $100 \mathrm{~m}^{-3}$ (total number of eggs and larvae found in the samples were multiplied by 100 and divided by the volume filtered).

Spatial and temporal variation of larvae of Anchoa sp. (Engraulidae), Syngnathus sp. (Syngnathidae), Gobiosoma sp. (Gobiidae), Clupeidae, Carangidae, and Atherinidae, and total eggs (spherical and Engraulidae elliptical egg) were correlated to environmental parameters. The correlation results were considered valid only when the frequency of occurrence was greater than $60 \%$ for both the temporal and the spatial variation.

\section{RESULTS}

Salinity ranged seasonally in the region from 42 in autumn (May 2010) to 53 in summer (February 2010), when evaporation is higher. Spatial variation demonstrated that salinity decreased towards the inner portion (station 8). In contrast to the spatial gradient between the inner areas and the entrance, monthly and seasonal changes were less evident in very shallow regions when compared to the deeper ones, suggesting that tide is not a factor affecting salinity in all the regions inside the lagoon equally. Our result reveal no significant influence of tide as a major factor affecting salinity as a whole (ANOVA, $p=0.22$ ). The temperature showed an overall average of $27.9^{\circ} \mathrm{C}$. The lowest temperatures were found in October 2010 (23.3
${ }^{\circ} \mathrm{C}$ ), while increases were found in January 2010 (32.1 ${ }^{\circ} \mathrm{C}$ ). Oxygen ranged from $3.08 \mathrm{mg} . \mathrm{L}^{-1}$ to $10 \mathrm{mg} \cdot \mathrm{L}^{-1}$ with an overall average of $6.36 \mathrm{mg} . \mathrm{L}^{-1}$. PH data were more acidic in February 2011, reaching 6.2 and more basic in January 2010 (9.3). The overall average $\mathrm{pH}$ was 8.15 (Figure 2).

The monthly distribution of fish eggs revealed a seasonal peak in spring and summer and fish larvae peaks before and at the end of the summer. Total egg density (Engraulidae elliptical eggs and unidentified spherical eggs) ranged from 10 to 365 eggs. $100 \mathrm{~m}^{-3}$, respectively in March 2010 and January 2011. Larvae of the following families and genera were registered in the region: Anchoa sp. (Engraulidae), Syngnathus sp. (Syngnathidae), Gobiosoma sp. (Gobiidae), Clupeidae, Carangidae, and Atherinidae. The highest abundance of larvae 203 larvae. $100 \mathrm{~m}^{-3}$ occurred in February 2011 (Tables 2 and 3) (Figure 3).

The peak of Engraulidae eggs was registered in December 2010, with a maximum of 314 eggs. $100 \mathrm{~m}^{-3}$. Eggs of unidentified families were also abundant, but mostly in October, when the figure reached 260 eggs. 100 $\mathrm{m}^{-3}$. The minimum, 6 eggs. $100 \mathrm{~m}^{-3}$, was observed in March 2010. Larvae of Atherinidae (55 larvae. $100 \mathrm{~m}^{-3}$ ), Syngnathidae (Syngnathus sp.) (3 larvae.100 $\mathrm{m}^{-3}$ ), and Engraulidae (Anchoa sp.) (118 larvae.100 $\mathrm{m}^{-3}$ ) showed a higher density in the middle of the austral summer (January or February), while Carangidae (5 larvae. $100 \mathrm{~m}^{-3}$ ), Clupeidae (41 larvae. $100 \mathrm{~m}^{-3}$ ), and Gobiidae (Gobiosoma sp.) (12 larvae. $\left.100 \mathrm{~m}^{-3}\right)$ peaked at the end of the summer (March) (Table 3) (Figure 3). 

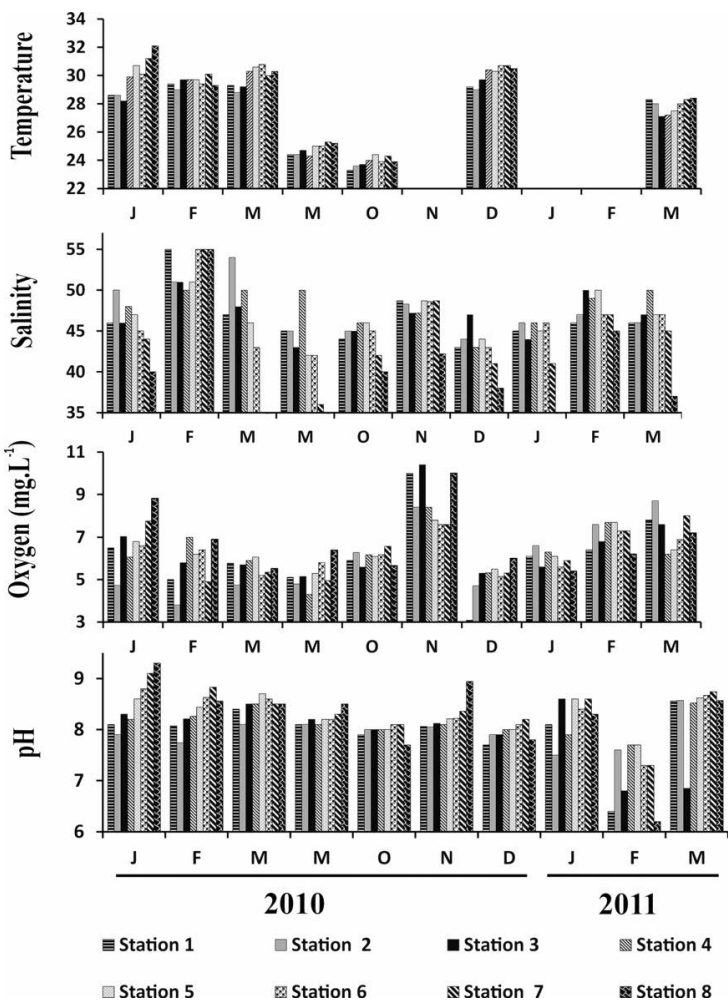

Figure 2. Environmental parameters salinity, temperature, oxygen and $\mathrm{pH}$ of the Lagoon of Araruama.

Considering the eight sampled areas, fish eggs and larvae were unevenly distributed in the lagoon. The higher densities that occur during the summer were not evident at the entrance nor in the inner areas, but at those stations located in the middle region and north margin of the lagoon (stations 3,4 , and 6).

\section{DISCUSSION}

According to the results presented herein, the Lagoa de Araruama is a hypersaline lagoon, in which the salinity is over 40 in almost all areas and throughout the year. In Brazil, hypersaline lagoons in subtropical regions usually have low-amplitude tides and high-salinity values (SILVA et al., 2005; SANTIAGO et al., 2005). Our results fail to reveal any significant relationship between tide and salinity such as has usually been observed in other studies (PINTO, 1976; COUTINHO et al., 1999), but monthly changes were more evident in deeper regions than those observed in shallow areas.

In general, the salinity in the Araruama lagoon seems to change seasonally according to the simultaneous effect of wastewater discharge in the inner portion and tidal intrusion of seawater through the channel. During the rainy season from January to May, when runoff is expected to be high, salinity decreases in the inner portion in relation to that at the entrance. These results support the findings that the discharge of wastewater combined with the seawater intrusions are actually affecting the salinity in the region, and that seasonality is more important than tide. This information corroborates the study by SOUZA et al. (2003), who claim that salinity varies only within the lagoon, at Ponta dos Excursionistas (site 8).

In terms of the spatial variation of the pond higher temperatures are found in the innermost part. CASTRO et al. (1999) also found higher results in the summer as also did the present study. The dissolved oxygen results did not show any spatial distribution trend towards more or

Table 2. Spatial distribution of egg density in the Lagoa de Araruama.

\begin{tabular}{lccccccccccc}
\hline stations/eggs & 1 & 2 & 3 & 4 & 5 & 6 & 7 & 8 & Average & Variables \\
\hline Jan.10 & 60 & 30 & 155 & 8 & 21 & 62 & 27 & 152 & 64 & 58 \\
Feb.10 & 41 & 48 & 41 & 46 & 4 & 38 & 0 & 16 & 29 & 19 \\
Mar.10 & 24 & 0 & 18 & 8 & 0 & 8 & 0 & 0 & 7 & 9 \\
May10 & 186 & 396 & 238 & 180 & 257 & 89 & 56 & 5 & 176 & 125 \\
Oct.10 & 313 & 111 & 471 & 630 & 632 & 571 & 153 & 7 & 361 & 249 \\
Nov.10 & 30 & 20 & 19 & 35 & 27 & 50 & 42 & 26 & 31 & 11 \\
Dec.10 & 3 & 10 & 71 & 1272 & 270 & 419 & 346 & 157 & 319 & 415 \\
Jan.11 & 211 & 123 & 1658 & 505 & 216 & 94 & 64 & 50 & 365 & 542 \\
Fev.11 & 6 & 12 & 329 & 115 & 218 & 56 & 203 & 116 & 132 & 112 \\
Mar.11 & 18 & 81 & 416 & 372 & 175 & 112 & 39 & 55 & 159 & 154 \\
Average & 89 & 83 & 342 & 317 & 182 & 150 & 93 & 58 & 164 & 110 \\
Variables & 108 & 118 & 491 & 402 & 192 & 188 & 110 & 61 & 139 & 155 \\
\hline
\end{tabular}


Table 3. Spatial distribution of larvae density in the Lagoa de Araruama.

\begin{tabular}{lccccccccccc}
\hline stations/larvae & 1 & 2 & 3 & 4 & 5 & 6 & 7 & 8 & Average & Variables \\
\hline Jan.10 & 29 & 7 & 4 & 0 & 39 & 34 & 85 & 203 & 50 & 68 \\
Feb.10 & 18 & 12 & 0 & 21 & 16 & 4 & 0 & 0 & 9 & 9 \\
Mar.10 & 0 & 0 & 0 & 4,5 & 0 & 4,5 & 0 & 0 & 1 & 2 \\
May 10 & 6 & 4 & 3 & 16 & 0 & 0 & 0 & 0 & 4 & 6 \\
Oct.10 & 9 & 19 & 42 & 42 & 9 & 6 & 6 & 6 & 17 & 16 \\
Nov.10 & 8 & 3 & 3 & 20 & 0 & 0 & 15 & 11 & 8 & 7 \\
Dec.10 & 0 & 0 & 3 & 0 & 3 & 0 & 3 & 10 & 2 & 3 \\
Jan.11 & 27 & 6 & 6 & 12 & 7 & 9 & 0 & 0 & 8 & 9 \\
Feb.11 & 6 & 6 & 22 & 16 & 12 & 946 & 76 & 78 & 145 & 325 \\
Mar.11 & 42 & 96 & 65 & 40 & 114 & 50 & 59 & 308 & 97 & 89 \\
Average & 12 & 15 & 15 & 17 & 20 & 105 & 24 & 62 & 34 & 33 \\
Variables & 14 & 29 & 22 & 15 & 35 & 296 & 35 & 108 & 49 & 96 \\
\hline
\end{tabular}
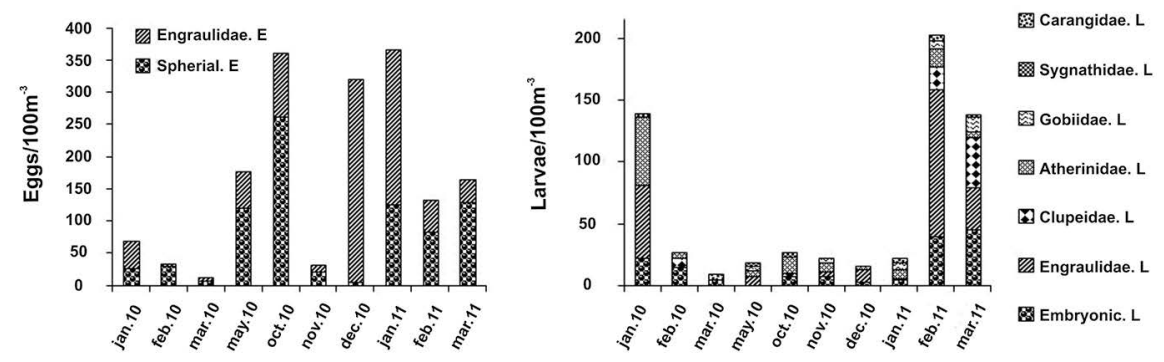

Figure 3. Monthly variation of fish eggs and larvae of the Lagoon of Araruama.

Table 4. Temporal correlation between data variation in the total number of egg and larvae with salinity and frequency of occurrence (FO).

\begin{tabular}{llll}
\hline Engraulidae larvae & $\mathrm{FO}=70 \%$ & $\mathrm{R}^{2}=0.513$ & $p=0.5290$ \\
\hline Carangidae larvae & $\mathrm{FO}=10 \%$ & $\mathrm{R}^{2}=-0.023$ & $p=0.67$ \\
Clupeidae larvae & $\mathrm{FO}=40 \%$ & $\mathrm{R}^{2}=0.015$ & $p=0.7685$ \\
Synathidae larvae & $\mathrm{FO}=40 \%$ & $\mathrm{R}^{2}=-0.0804$ & $p=0.4274$ \\
Atherinidae larvae & $\mathrm{FO}=90 \%$ & $\mathrm{R}^{2}=0.0058$ & $p=0.8338$ \\
Gobidae larvae & $\mathrm{FO}=50 \%$ & $\mathrm{R}^{2}=0.0148$ & $p=0.7378$ \\
Embryonic larvae & $\mathrm{FO}=90 \%$ & $\mathrm{R}^{2}=0.1081$ & $p=0.3537$ \\
Engraulidae eggs & $\mathrm{FO}=100 \%$ & $\mathrm{R}^{2}=0.2440$ & $p=0.1468$ \\
Eggs of unidentified families & $\mathrm{FO}=100 \%$ & $\mathrm{R}^{2}=-0.0906$ & $p=0.3981$ \\
Total Eggs & $\mathrm{FO}=100 \%$ & $\mathrm{R}^{2}=-0.5182$ & $p=0.0189$ \\
\hline
\end{tabular}

less greatly benefited points at any time during the study period. According to PEREIRA (2007), eutrophication causes significant changes in $\mathrm{pH}$, concentration of nutrients and dissolved oxygen in a short period of time, increasing the concentration of methane and hydrogen sulfide gases, and the biota, including: changes in the diversity and density of organisms. The tendency of a basic $\mathrm{pH}$ in the pond can be related microalgae that remove $\mathrm{CO}_{2}$ from $\mathrm{H}_{2} \mathrm{CO}_{3}$ molecules present in the water that makes the basic
$\mathrm{pH}$ with excess calcium and magnesium ions in water cyanobacteria remove these ions and precipitate calcite and magnesian calcite (Arp et al., 2002).

The spatial distribution of fish eggs and larvae in the Lagoa de Araruama was influenced by the dilution gradient from the entrance to the inner areas. Higher abundances were seasonally displaced from those areas closer to the entrance, where adults seem to release their eggs, to the middle and inner portion, where the larvae develop. The 

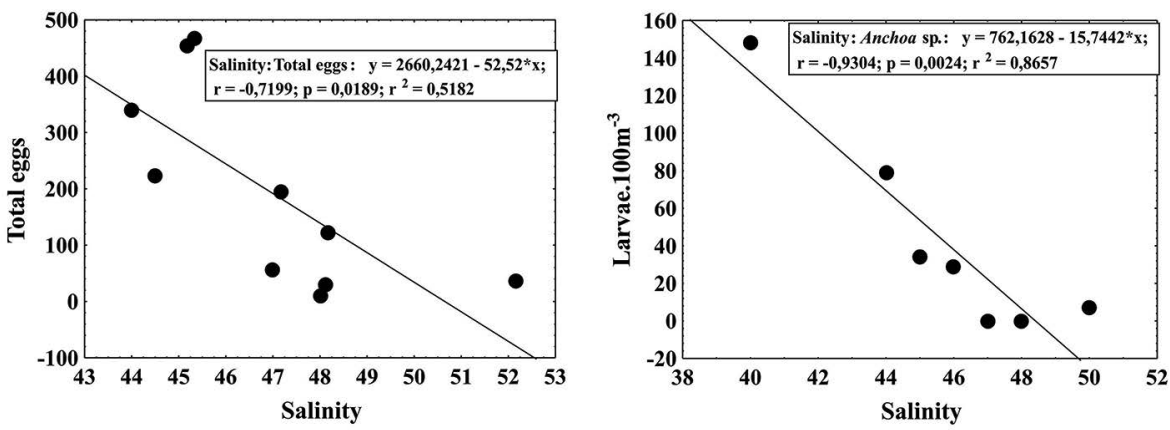

Figure 4. Correlation between salinity and eggs and larvae of the Lagoon of Araruama.

absence of high densities of eggs and larvae in those sites in the middle region but closer to the sea lead us to conclude that both adults and larvae are inhabiting more protected areas, where either competition or top predation could affect eggs and larval survival.

The low density of eggs and larvae registered in this study supports that tendency previously revealed by CASTRO et al. (1999) who related it to the food web structure. And this despite the fact that some areas inside the lagoon can sustain high primary production due to the high nutrient level.

Due to the high irradiance regime, only a few species can inhabit this hypersaline ecosystem. CASTRO et al. (1999) also refer to the high salinity allied to the low depth that could be the main limiting factor explaining the low number of eggs and fingerlings in the lagoon. The low plankton density in the Lagoa de Araruama was also mentioned by COUTINHO et al. (1999), who affirmed that the rise in salinity influenced the plankton community. On a global scale, BUSKEY et al. (1998) claimed that hypersaline estuaries with salinity between 41 and 50 are usually characterized by low richness and low average abundance of zooplankton.

Our results added the families Engraulidae, Clupeidae, Carangidae, Syngnathidae, Atherinidae, and Gobiidae to the list of registered taxa in the lagoon. Some of these families were also found by MUREB (1982) in the same region. In addition to these families Mureb also found Balistidae, Flopidae, Gerreidae, Nomeidae, Scianidae, Scombridae, and Serranidae. In contrast to MUREB (1982), CASTRO et al. (1999) found fewer but different fish families in the same region (Hemiramphidae, Atherinidae, Syngnathidae, Sparidae and Blennidae), but among the species found by CASTRO (1999) two were present in the current study. The differences between the current ichthyoplankton composition in the lagoon from that found by CASTRO et al. (1999) and MUREB (1982) may be related to a potential interannual trend to a decrease in salinity, in view of the decrease in average salinity registered over the decades - 64 in 1978 and 1979 (MUREB, 1982) and from 61 to 48 in 1995 (CASTRO et al., 1999) - down to 45 in 2010 and 2011.

The families Engraulidae, Clupeidae, and Gobiidae, whose eggs and larvae showed the highest abundances, are usually found in other estuaries on the Brazilian coast as dominant taxa (JOYEUX et al., 2004). As was to be expected, the eggs of these families were more abundant during the austral spring and summer, supporting the findings of other studies that indicate spawning in the warm seasons (CASTRO et al., 2005; FRANCO; MUELBERT, 2003; AROCKIAMARY et al., 2011; KATSURAGAWA et al., 2011). Besides fish phenology, that could explain the larger part of the egg and larval distribution in the Lagoa de Araruama region: some interannual variation in the dilution gradient is necessary to describe the unexpectedly high densities found during fall and winter, as observed by CASTRO et al. (1999). Interannual differences in the ichthyoplankton dominance, from Atherinella brasiliensis (Atherinidae) in 1995 (CASTRO et al., 1999) to Anchoa sp. (Engraulidae) in 2010/2011 could also be related to the same effect.

The significant negative relationship between both eggs and larvae of Anchoa sp. (Engraulidae) and salinity may be due to the osmoregulatory physiology of Engraulidae larvae. According to OPSTAD (2003), "the skin of teleost larvae consists of an epithelium with two thin layers, without gill filaments, whose kidney exists only as a pronefrone glomerus. Thus, the larvae do not have osmoregulatory mechanisms as adults do, something which restricts their distribution in areas where salinity facilitates the osmotic movement between the epithelial surface and the water around it. Moreover, both larval 


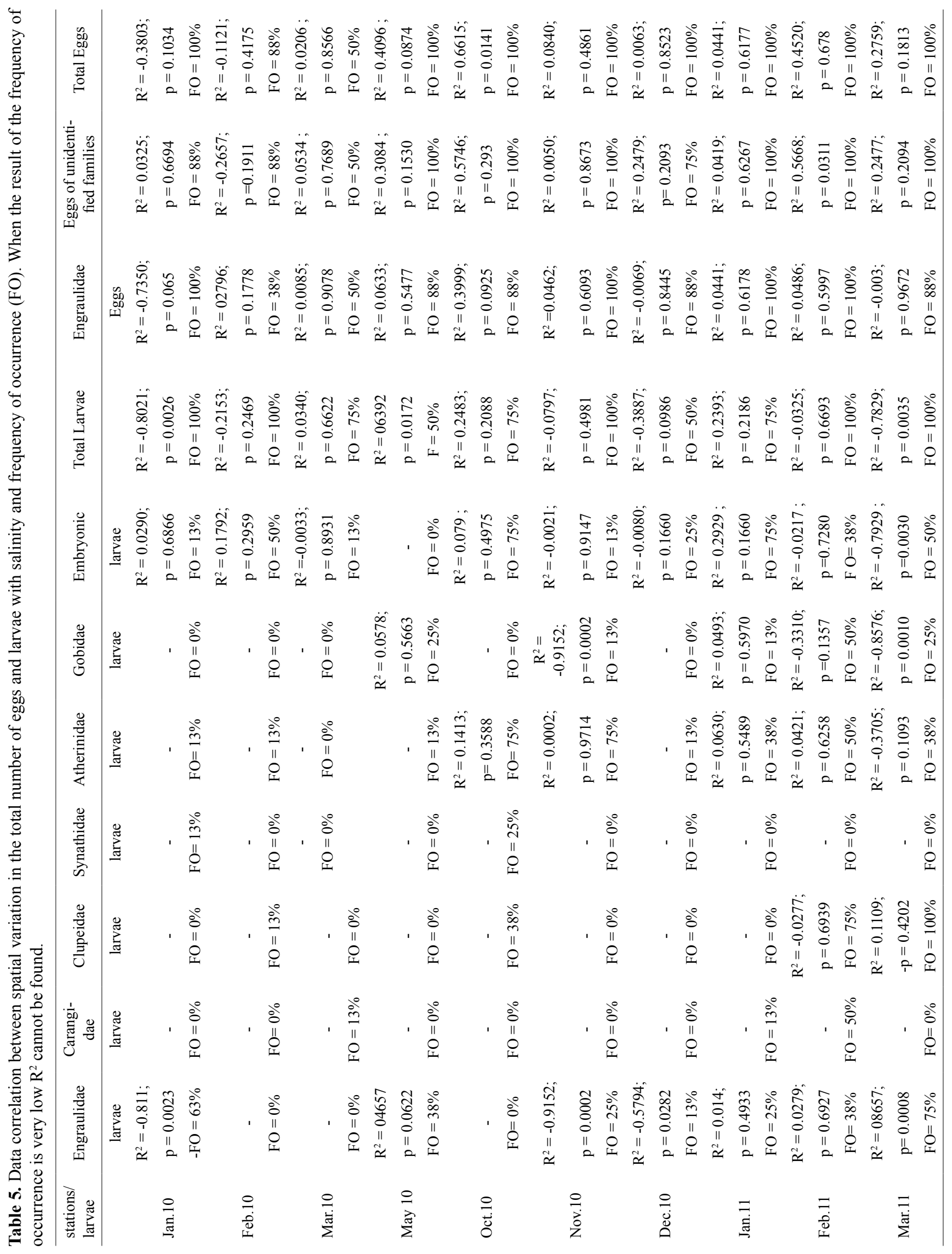


survival and growth can increase by grading the osmotic relation of the body to water, reducing the energetic costs in an isosmotic environment". GOARANT (2007) found similar results, in which salinity presents an important correlation with Anchovy (Engraulis encrasicolus) eggs. This helps us to understand the wide variety observed in the composition and abundance of ichthyoplankton in the Lagoa de Araruama. This hypothesis has already been raised by COUTINHO et al. (1999) as an explanation for the few fish species that breed there.

\section{ACKNOWLEDGEMENTS}

The author wishes to thank the Intermunicipal Consortium Lagos São João, which funded the study, and Prolagos, which analyzed salinity at the study location.

\section{REFERENCES}

AROCKIAMARY, A.; VIJAYALAKSHMI, S.; BALASUBRAMANIA, T. Engraulidae eggs from Parangipettai waters. Eur. J. Exp. Biol., v. 1, n. 2, p. 125-131, 2011.

ARP, G.; REIMER, A.; REITNER, J. Calcification of cyanobacterial filaments: Girvaneila and the origin of Lower Paleozoic lime mud: comment and reply. Geology, v. 30, p. 579-580, 2002.

BARLETTA-BERGAN, A.; BARLETTA, M.; SAINT-PAUL, U. Structure and Seasonal Dynamics of Larval Fish in the Caeté River Estuary in North Brazil. Estuar. Coast. Shelf Sci. v. 54, n. 2, p. 193-206, 2002.

BONECKER, ACT; BONECKER, A LCE; BASSANI, C. Plâncton Marinho. Em: PEREIRA, R. C. \& SOARES-GOMES, A (editores). Biologia Marinha. Rio de Janeiro: Interciência, 2009.

BRUSKEY, E. J.; WYSOR, B.; HYATT, C. The role of hypersalinity in the persistence of the Texas 'brown tide' in the Laguna Madre. J. Plankton Res., v. 20, n. 8, p. 1553-1565, 1998.

CASTRO, M. S.; BONECKER, A. C. T. Ocorrência de larvas de peixe no sistema estuarino do Rio Mucuri. Arq. Biol. Tecnol., v. 39, n. 1, p. 171-185, 1996.

CASTRO, M. S.; BONECKER, A. C. T.; VALENTIN, J. L. Ichthyoplankton of a permanently hypersaline coastal lagoon: Lagoa de Araruama, Brazil. J. Trop. Ecol., v. 40, n. 2, p. 221227, 1999.

CASTRO, M. S.; BONECKER, A. C. T.; VAlENTIN, J. L. Seasonal variation in fish larvae at the entrance of Guanabara Bay, Brazil. Braz. Arch. Biol. Technol., v. 48, n. 1, p. 121-128, 2005.

COSTA, M. P. V.; SILVA, R. Z.; SAMPAIO, L. A. Morfogenia larval microantômica do peixe-rei marinho Odontesthes argentinensis (Atheriniformes, Atherinopsidae) do Rio Grande do Sul-Brasil: entre a eclosão e o $30^{\circ}$ dia. Biociências, v. 17, n. 1, p. 91-105, 2009.

COTNER, J. B.; SUPLEE, M. W.; CHEN, N. W.; SHORMANN, D. E. Nutrient, sulfur and carbon dynamics in a hypersaline lagoon. Estuar. Coast. Shelf Sci., v. 59, n. 4, p. 639-652, 2004.
COUTINHO, R.; RIBEIRO, P.; KJERFVE, B.; KNOPPERS, B.; MUEHE, D.; VALENTIN, J. L. Araruama, uma lagoa ameaçada. Ciênc. Hoje, v. 25, n. 149, p. 24-31, 1999.

DAY, J. W. J.; HALL, C. A. S.; KEMP, W. M.; YÁNEZARANCIBIA, A. Estuaria Ecology. New York: Oxford University Press, 1989.

FRANCO, B. C. ; MUELBERT, J. H. Distribuição e composição do ictioplâncton na quebra de Plataforma do Sul do Brasil. Atlântica, v. 25, n. 1, p. 75-86, 2003.

GOARANT, A.; PETITGAS, P.; BOURRIAU, P. Anchovy (Engraulis encrasicolus) egg density measurements in the Bay of Biscay: evidence for the spatial variation in egg density with sea surface salinity. Mar. Biol, v. 151, n. 5, p. 1907-1915, 2007.

JOYEUX, J. C.; PEREIRA, B. B.; ALMEIDA, H. G. The floodtide ichthyoplanktonic community at the entrance into a Brazilian tropical estuary. J. Plankton Res., v. 26, n. 11, p. 1277-1287, 2004.

KATSURAGAWA, M.; ZANI-TEIXEIRA, M. L.; GOÇALO, C. G.; OHKAWARA, M. H.; ITAGAKI, M. K. Ichthyoplankton distribution and abundance in the northern Todos os Santos and Camamu Bays, Bahia state - Brazil. Braz. J. Oceanogr., v. 59, n. 1, p. 97-109, 2011.

MUREB, M. A. R. O Ictioplâncton das Águas Hipersalinas da Lagoa de Araruama - Observações Preliminares. Relatório Preliminar para o CNPq, 1982. 26 p.

OPSTAD, I. Growth and survival of haddock (Melanogrammus aeglefinus) larvae at different salinities. In: BROWMA, H. I.; SKIFTESVIK, A. B (Eds.). The Big Fish Bang. Proceedings of the 26th Annual Larval Fish Conference. Bergen: Institute of Marine Research, 2003. p. 63-69.

PEPIN, P.; DOWER, J. F.; DAVIDSON, F. J. M. A spatially explicit study of prey-predator interactions in larval fihs: assessing the influence of food and predator abundance on larval growth and survival. Fish. Oceanogr., v. 12, n. 1, p. 19-33, 2003.

PEREIRA, L. F. M. A gestão participativa no caso do saneamento da região dos Lagos, Rio de Janeiro. Rev. Disc. Exp. Geogr., v. 3, p. 10-41, 2007.

PINTO, N. L. S.; HOLTZ, A. C. T; MARTINS, J. A.; GOMIDE, F. L. S. Hidrologia Básica. 2a. ed. São Paulo: Edgard Blücher, 1976. 278 p.

REYIER, E. A.; SHENKER, J. M. Ichthyoplankton community structure in a shallow subtropical estuary of the Florida Atlantic coast. Bull. Mar. Sci., v. 80, n. 2, p. 267-293, 2007.

SANTIAGO, M. F.; PASSAVANTE, J. Z. O.; SILVA-CUNHA, M. G. G. Caracterização de parâmetros físicos, químicos e biológico em ambiente hipersalino, estuário do rio pisa sal (Galinhos, Rio Grande do Norte, Brasil). Trop. Oceanogr. Recife, v. 33, n. 1, p. 39-55, 2005.

SILVA, L. H. S;. DAMAZIO, C. M.; IESPA, A. A. C. Identificação de cianobactéricas em sedimentos da Lagoa Pitanguinha, estado do Rio de Janeiro, Brasil. Anu. Inst. Geocienc., v. 28, n. 1, p. 92-100, 2005.

SOUZA, M. F. L.; KJERFVE, B.; KNOPPERS, B.; LANDIMDESOUZA, W. F.; DAMASCENO, R. N. Nutrient budgets and trophic state in a hypersaline coastal lagoon: Lagoa de Araruama, Brazil. Coast. Shelf Sci., v. 57, p. 843-858, 2003. 